\title{
THE "STRONG MAN" AT DARTMOUTH COLLEGE: TWO UNCOLLECTED PARODIES OF WHITMAN'S “AS A STRONG BIRD ON PINIONS FREE”
}

\author{
TODD RICHARDSON
}

ONE DAY AFTER Walt Whitman delivered his poem "As a Strong Bird on Pinions Free" to the graduating class of Dartmouth College on June 26, 1872, he asked his friend Peter Doyle, "did my poem appear in the Washington papers . . . Chronicle or Patriot? If so, send me one" (Corr. $2: 181)$. The inquiry and the subsequent search, which turned out to be fruitless for both Doyle and later scholars, underscores Whitman's abiding concern over his reputation in the American press. Until recently, scholars have focused their efforts on uncovering press releases and reviews of the commencement poem primarily where Whitman, as noted above, has provided clues, and in representative metropolitan dailies. The seeming paucity of press material has led many to conclude that the event proved to be uninteresting for newspaper editors, disappointing Whitman's efforts to promote and later sensationalize the reading. ${ }^{1}$ The press coverage for the event, however, was in fact much fuller than has been previously thought, indicating that Whitman's reputation commanded the attention (if not always the respect) of major papers even when he was far from metropolitan centers. Most significantly, the reading precipitated at least two parodies within days of the reading-a noteworthy response for a poem delivered several states away.

Scholars have acknowledged that the poet sent copies of his commencement poem to metropolitan papers several days in advance of the reading, including the New York Herald and the Boston Daily Advertiser (Corr. 2:179, 5:295). To this list I add the New York papers the Post (which printed Whitman's poem on June 26, 1872) and the World (which printed it on June 27, 1872). ${ }^{2}$ While the Post printed an unfavorable review of the poem on June 27, the World awarded Whitman's work the dubious honor of two parodies. ${ }^{3}$ Although I have not determined who penned the parodies, it seems likely that managing editor David G. Croly (1829-1889) was involved, as he and Whitman were acquainted. Additionally, Croly was instrumental in setting the democratic editorial agenda of the paper. ${ }^{4}$ The World printed the first parody on June 28,1872 , only one day after it had published the original poem. ${ }^{5}$ The text is as follows: 
If there be any incoherence of ideas in our columns to-day, or to-morrow, or the day after to-morrow, or any other time up to the middle of next week,

Set it not down, O reader, to softening of the brain, nor efforts to discover the reasons for Mr. Greeley's nomination, nor hopelessness as to the prospect of ever seeing New York cleaned, nor any other ordinary provocative of dulness;

But only to the fact that all the people in this office-the editor, reporter, proofreader, compositor, devil - have been bothering their brains over Walt Whitman's Dartmouth commencement poem,

And trying to find out what he means, and why he means it in that extraordinary manner.

The World's bewildered acknowledgment of Horace Greeley's winning the Democratic primary capped off the newspaper's active campaign against the founder of the New York Tribune and signaled its eventual support for the nominee. The bemused (and amused) response both to Whitman's poem and to Greeley's nomination continued on June 30 with a more carefully crafted parody which mocks the form and content of Whitman's "Strong Bird." The reference to "H.G." in line eleven is, of course, Horace Greeley. The full text is as follows:

\section{"As a Strong Man with Bunions Three!" BY A. WILTED WHITEMAN.}

I.

As a strong man, with bunions three,

Lachrymose, as though on red-hot iron treading,

Groans with despairing voice and chiropodistic cries-

Such be the unfathomable agony of mine inmost feeling!

\section{II.}

The conceits of iconoclasts, of hypophagi, of eleemosynary, prismatic poet-laureates, Of indefatigable archaeologists - the reverberating music of the ocean waves-

These are but a drop in the domestic receptacle for containing water,

Compared with the ceaseless labor-pains of my maternal muse!

III.

The impenetrable nonentities spewed forth from the cornucopia of our forefathers' iniquities!

Measles! Scarletina! [sic] The terrible cerebra-spinal-meningitis!

And the political contortions, the grand and lofty tumbling of $\mathrm{H}$. G.-

Like the angles of some Antarctic circle, these are limitless!

IV.

O, Ossian! O, Homer! O, Dante! O, Fiddlesticks!

Is not the masculine dweller of the lynx-eyed moon a purveyor of condensed milk?

And am I not the great modern upheaver of the universe of song?

Priestly Asia, ghostly Patagonia, Europe feudal, and galloping Yankee Doodle, answer me!

ECHO: Oh, Hush! Give Pegasus a rest! 
Divided into five cantos like "As a Strong Bird," the parody insists on Whitman's arrogance, particularly through its implication that he claims for himself, with pretentious verbiage, a place in the poetic pantheon with the likes of Ossian, Homer, and Dante. The writer, of course, spoofs Whitman's poetic claims specifically: for example, Whitman's "Joyous, the amplest spaces heavenward cleaving" becomes "Lachrymose, as though on red-hot iron treading," and his "The conceits of the poets of other lands" becomes "The conceits of iconoclasts, of hypophagi, of eleemosynary, prismatic poet laureates."

Because of his challenge to poetic conventions generally, Whitman's poetry was a favorite target for writers of parody of the late nineteenth century. Until now, however, only eight have been located between the years 1860 and $1880 .{ }^{6}$ Most likely more topical parodies of Whitman and his work have yet to be discovered from this period, because, of course, Whitman experienced momentous events during this time: his dismissal from the Department of the Interior in 1865, the publication of William Michael Rossetti's edition of Whitman's poetry in 1868, and Robert William Buchanan's criticism, in 1876, of the American literary world for its ongoing condemnation of Whitman. Also during this time, Whitman published Democratic Vistas and several new editions of Leaves of Grass.

\section{University of South Carolina}

\section{NOTES}

1 See especially Emory Holloway's "Whitman as his Own Press Agent" (American Mercury 18 [December 1929], 482-488) and Gay Wilson Allen's The Solitary Singer (New York: MacMillan, 1955), 442. More recently, Jerome Loving's Walt Whitman: The Song of Himself (Berkeley: University of California Press, 1999) has provided newly discovered material on the reading from the Dartmouth archives and from Burlington, Vermont, and Concord, New Hampshire, newspapers (341-345).

2 See Joel Myerson's Walt Whitman: A Bibliography (Pittsburgh: University of Pittsburgh Press, 1993), 777, and Scott Giantvalley's Walt Whitman, 1838-1939: A Reference Guide (Boston: G. K. Hall, 1981), 33. The text of the poem in the World and the Post differs slightly in capitalization and punctuation from the text of Whitman's selfpublished As a Strong Bird on Pinions Free (Washington, D. C., 1872), 1-7.

3 Jerome Loving's assessment that reviews were mixed (343) accurately describes the two additional notices of the event that I located:

June 28, 1872, New York Post:

The Poem (?) Of Walt Whitman was thirteen minutes in length, and just that much too long. The house was full when he began, but during the next ten minutes there was a wonderful dispersal. This was the first poem that Mr. Whitman has prepared for such an occasion, and we trust that he will not often be called upon to repeat it.

June 27,1872, Newark (N. J.) Daily Advertiser (reprinted July 4, 1872, Baltimore Morning Sun and July 6, 1872, Washington Evening Star): 
The original poem read by Walt Whitman at the Dartmouth Commencement yesterday was a trifle more rational in idea and expression than was expected. It was like a grand old Greek panegyric; prophesying the greatness in store for our country, abounding in fine metaphor, and lacking the cataloguical style characteristic of his former efforts. Whatever may be said of Whitman, in ridicule, he has a sturdy, noble masculinity that presents a refreshing contrast to the sickly sentimentalism called poetry now-a-days. He breathes into his lines an air of freedom and vigorous life that the languishing closet poets deem too rude for their fragile numbers. Perhaps, after all, there is more true poetry in his wild, untrammeled nature than in all the 'fleshly' rhyme and rhythm in the world.

4 See Horace Traubel's With Walt Whitman in Camden (1914; rpt. New York: Rowman and Littlefield, 1961), 3:560-561, and American National Biography (New York: Oxford University Press, 1999), 3:756.

5 The parody was reprinted in the Newark (N. J.) Daily Advertiser of June 28, 1872, with a swipe at the World for its recent "retrograde" move towards supporting Horace Greeley. On July 1, the editors for the World wrote, "Our readers know how earnestly we have deprecated the result [Greeley's nomination], but . . . we must make the best of it."

6 See Henry Saunders's Parodies on Walt Whitman (New York: American Library Services, 1923) and Giantvalley's Walt Whitman, 1838-1939: A Reference Guide. 